\title{
Academic Stress in Postgraduate Student from a Private Peruvian University in the COVID-19 Context
}

\author{
${ }^{1}$ Manuel Angel Pérez Azahuanche, ${ }^{2}$ Beymar Pedro Solis Trujillo, ${ }^{3}$ Mercedes Alejandrina Collazos Alarcón, \\ ${ }^{4}$ Hiroshi Kenyi Meza Carbajal, ${ }^{5}$ Lindon Vela Meléndez, ${ }^{6}$ Enaidy Reynosa Navarro, ${ }^{7}$ Arturo Barraza Macías
}

${ }^{1}$ Universidad César Vallejo, Perú

${ }^{2}$ Universidad César Vallejo, Perú

${ }^{3}$ Universidad César Vallejo, Perú

${ }^{4}$ Universidad César Vallejo, Perú

${ }^{5}$ Universidad Nacional Pedro Ruiz Gallo, Perú

${ }^{6}$ Universidad César Vallejo, Perú

${ }^{7}$ Universidad Pedagógica Nacional, Durango, México

\begin{abstract}
RESUMEN
The present research of descriptive scope with transectional design, is framed in the quantitative route, had like objective to measure the level of academic stress to which the students of postgraduate of the University Cesar Vallejo of Peru are put under, in the context COVID-19. The methodology highlights the application of an authorized instrument called SISCO Inventory for the measurement of academic stress, which was applied to 406 students of the masters and doctoral programs of the mentioned institution. The main results show the presence of academic stress in $93.3 \%$ of the students, with a high intensity that is explained by the fact that $83.3 \%$ are in levels 3, 4 and 5 of the scale, considering that 5 is the level of high stress. Finally, the main stressors found were the overload of daily academic activities, reactions to anxiety, anguish or desperation, and as the main coping strategy to recover the systemic balance, the analysis of the positive and negative arguments of the solutions designed to remedy the situations that generate the stress.
\end{abstract}

Keywords: stress; academic stress; mental stress; COVID-19

\section{Introduction}

The world's population is currently experiencing an exceptional situation that has led to a disruption in political, economic, public health and educational terms due to the proliferation of the COVID-19 despite the great efforts made by governments at the global level. The progress of this disease has been so irrefutable that it is considered by many to be the first global pandemic in history (Segura, 2020). In December 2019, COVID-19 caused an outbreak of infectious pneumonia, for which the government of the People's Republic of China took important measures to prevent its spread. However, this affected scientific researchers who were found to have higher levels of stress, as well as students in that nation, who are close to completing their degrees and graduating as teachers and doctors during 2020 (Zhang et al., 2020); (Wu et al., 2020). In this way, a series of infections were triggered, linked to a high perception of risk that affected not only health professionals, but also students and especially those linked to public health.
Data from the International Institute for Higher Education in Latin America and the Caribbean (2020) show that in Latin America more than $23,400,000$ students and 1,000,400 teachers have had to make the transition from physical to virtual environments, which has been both complex and demanding. In order for a teacher or student to adapt to this new way of teaching and learning, they have to think about implementing new didactic strategies at a synchronous and asynchronous level, which are very different from those used in normal situations. Teachers must develop professional skills to help them teach online, and they recommend that teachers in regular and special schools be trained in information technology to make their work effective (Mahapatra \& Sharma, 2020). All these abrupt changes and the poor infrastructure in our country's network result in frustration, anxiety and stress for all those involved in the various academic activities.

COVID-19 affects university students, especially in terms of their university development and 
academic performance (Rodríguez De Los Ríos et al., 2020). Stress can affect them physically, emotionally and in their behavior. Academic stress can also be caused by academic stressors in the teaching and learning process or in matters related to learning activities and generate academic pressure on them (Sari et al., 2020). However, for them this kind of pressure is natural; but if such pressures are accompanied by inconsistencies in virtual educational models and their changes in social dynamics, then it would result in considerable emotional burnout (Alania Contreras et al., 2020).

Research by Ozamiz-Etxebarria et al. showed that the highest levels of stress and depression symptoms occurred after the order to stay home was issued (Ozamiz-Etxebarria et al., 2020). These symptoms are expected to increase as the confinement continues. From the findings, it appears that university students who have a need for different academic activities in addition to confinement tend to feel more stress and anxiety. The main stressor that generates high levels of stress is academic overload. This affects both university students, who have resorted to religiosity to cope with it (Pedroza et al., 2019) and the implementation of educational programmes (Trigueros et al., 2020), because these enrich the dynamics in the development of the classes, making the students motivated and channeling academic stress in a positive way. In this sense, the administrative teams of the universities must organize awareness activities for students and teachers in order to make known the emerging academic stressors and their efficient ways of managing them (Adom et al., 2020). Another alternative for reducing academic stress, overcoming workloads and rigid delivery schedules, is the active participation of individuals and support in individual and shared resources (Procentese et al., 2020).

In another study on the psychological impact of COVID-19 on the university community during the first weeks of confinement in students at a University of Valladolid, Spain, they found a significant increase in anxiety, depression and stress. Therefore, it is necessary to take into account the mental health of university students at this stage (Odriozola-González et al., 2020). It is considered that the overall impact on education and mental health in the Spanish university environment caused by the COVID-19 infection is considerable, resulting in a notable increase in student stress (Sahu, 2020).

In Latin American countries, governments opted for the confinement of their population, establishing measures of social distancing, use of masks, as well as the use of face shields, among others. Although social distancing has been shown to help reduce the spread of the disease and prevent health systems from collapsing (Fernández-Sánchez et al., 2020), it has also led to people being psychologically affected, experiencing anxiety, fear, depression and stress. Consequently, this situation has been affecting social dynamics, the economic factor, the education sector, among others (Lozano Díaz et al., 2020); the feelings most frequently experienced being anxiety, worry or fear in relation to one's health status (OPS, 2019). Another aspect to take into account is the situation of the vulnerable population, which is undoubtedly the most affected, being exposed to a psychosocial impact that could exceed their capacity for self-control. In this sense, it is estimated that the incidence of mental disorders and emotional manifestations will increase, according to the magnitude of the epidemic and the degree of vulnerability of the population (Ribot et al, 2020).

All the analysis carried out so far provides complex elements that support the following research question: What are the levels of stress to which graduate students at the Universidad César Vallejo, Peru, are subjected in the times of COVID-19? It is presented as a general objective, 
to determine the level of academic stress of the students of the University César Vallejo, Peru, in times of COVID-19. The specific objectives were: to identify the stressful stimuli, the reactions or symptoms in front of the stressful stimuli and the identification of the strategies of coping with the stress in order to reestablish the systemic balance that is lost with the stress.

\section{Methodology}

Initially, the components of the variable were identified in order to evaluate and define the appropriate technique and instrument to be used (Hernandez et al., 2014). The decision was made to apply the Cognitive Systemic Inventory for the study of academic stress, second version of 21 items (SISCO Inventory of Academic Stress) by Arturo Barraza Macias, who authorized its use and application. The inventory consists of 21 items and contains an initial filter that determines whether or not the respondent can be a candidate to answer the subsequent questions; it is structured with five answer options with Likert type scaling. It asks how often the person becomes anxious about various situations; how often they present physical, psychological and behavioral reactions when they are worried or nervous and how often they use certain strategies to cope with the situations that give rise to them (Barraza, 2007).

The study is cross-sectional, descriptive and quantitative; the sample was probabilistic and was calculated based on a population of 18,000 students in graduate programs (masters and doctoral). The calculated sample size was 376 students, given the type of study, the same that requires an initial filter was considered the figure of 406 .

Table 1. Instrument Reliability: Total Item Statistics
Sample calculation:

$$
\mathrm{n}=\left(\mathrm{N}^{*} \mathrm{p} *(1-\mathrm{p}) * \mathrm{Z}^{2}\right) /\left[\mathrm{e}^{2}(\mathrm{~N}-1)+\mathrm{p} *(1-\mathrm{p}) * \mathrm{Z}^{2}\right]
$$

$\mathrm{N}$ : Population, $\mathrm{p}$ : Percentage of the population that has the desired attribute, e: Maximum accepted estimation error, Z: Confidence level

$$
\begin{aligned}
& \mathrm{n}=\left(18,000 * 0.5 * 0.5 * 1.96^{2}\right) /[0.052(18,000-1)+ \\
& \left.0.5 * 0.05 * 1.96^{2}\right]=376
\end{aligned}
$$

The instrument was administered in digital format through an online form and was available for students to answer for 15 days. For the treatment of the information, descriptive statistics were used, proceeding initially to tabulate the data and elaborate the frequency tables by levels of stress, stressors, reactions or symptoms and coping mechanisms. The reliability of the instrument was checked and the results were analyzed and interpreted.

To safeguard the moral integrity of the participants, anonymity was guaranteed. They were also informed about the purpose of the research and its limits. As the instrument was not developed by the authors of this study, the legitimate author was contacted and, through a written and signed notification, gave his or her consent to its adaptation and use exclusively for research purposes.

\section{Results}

The reliability of the instrument was initially analyzed in the context of the study. Cronbach's Alpha statistician was used and found a high level of reliability of the instrument, reaching an index of 0.944 in the 21 substantial questions aimed at measuring academic stress (Table 1).

\begin{tabular}{ccccc}
\hline & Scale & Variance & Total & Cronbach's \\
Questions & average & of scale & correlation & Alpha if \\
if the & if the & of & the element
\end{tabular}




\begin{tabular}{|c|c|c|c|c|}
\hline & $\begin{array}{l}\text { element } \\
\text { has been } \\
\text { deleted }\end{array}$ & $\begin{array}{c}\text { element } \\
\text { has been } \\
\text { deleted }\end{array}$ & $\begin{array}{c}\text { elements } \\
\text { corrected }\end{array}$ & $\begin{array}{c}\text { has been } \\
\text { deleted }\end{array}$ \\
\hline $\begin{array}{l}\text { Stress from overload of homework } \\
\text { and daily schoolwork }\end{array}$ & 50,45 & 343,512 & ,697 & ,941 \\
\hline $\begin{array}{l}\text { Stress due to the personality and } \\
\text { character of the teachers who teach } \\
\text { me }\end{array}$ & 51,62 & 342,898 & ,610 & ,942 \\
\hline $\begin{array}{l}\text { Stress over the way my teachers are } \\
\text { evaluated }\end{array}$ & 51,07 & 338,030 & ,703 & ,940 \\
\hline $\begin{array}{l}\text { Stress due to the level of demand of } \\
\text { my teachers }\end{array}$ & 51,16 & 340,370 & ,682 & ,941 \\
\hline $\begin{array}{l}\text { Stress about the kind of work that } \\
\text { teachers ask me to do }\end{array}$ & 50,98 & 339,489 & ,690 & ,940 \\
\hline $\begin{array}{l}\text { Stress due to the limited time to do } \\
\text { the work that the teachers entrust me } \\
\text { with }\end{array}$ & 50,55 & 338,057 & ,713 & ,940 \\
\hline $\begin{array}{l}\text { Stress over how unclear I am about } \\
\text { what the teachers want }\end{array}$ & 51,33 & 342,005 & ,650 & ,941 \\
\hline $\begin{array}{l}\text { Stress reaction: Chronic fatigue } \\
\text { (permanent tiredness) }\end{array}$ & 51,05 & 341,130 & ,670 & ,941 \\
\hline $\begin{array}{l}\text { Reaction to stress: Feelings of } \\
\text { depression and sadness (drooping) }\end{array}$ & 51,35 & 341,196 & ,662 & ,941 \\
\hline $\begin{array}{l}\text { Reaction to stress: Anxiety, distress } \\
\text { or despair }\end{array}$ & 51,03 & 338,732 & ,690 & ,940 \\
\hline $\begin{array}{l}\text { Reaction to Stress: Concentration } \\
\text { Problems }\end{array}$ & 51,11 & 342,871 &, 703 & ,940 \\
\hline $\begin{array}{l}\text { Reaction to stress: Feeling of } \\
\text { aggression or increased irritability }\end{array}$ & 51,69 & 341,023 & ,612 & ,942 \\
\hline $\begin{array}{l}\text { Reaction to stress: Conflict or } \\
\text { tendency to argue }\end{array}$ & 51,74 & 344,131 & ,616 & ,942 \\
\hline $\begin{array}{l}\text { Reaction to Stress: Unwillingness to } \\
\text { do school work }\end{array}$ & 51,37 & 342,986 & ,617 & ,942 \\
\hline $\begin{array}{l}\text { Coping Strategy: Focus on solving } \\
\text { the situation that concerns me }\end{array}$ & 50,20 & 343,020 & ,648 & ,941 \\
\hline $\begin{array}{l}\text { Coping strategy: Establish concrete } \\
\text { solutions to resolve the situation that } \\
\text { concerns me }\end{array}$ & 50,13 & 342,166 & ,664 & ,941 \\
\hline $\begin{array}{l}\text { Coping strategy: Analysis of the } \\
\text { positive and negative aspects of the } \\
\text { solutions designed to solve the } \\
\text { situation that concerns me }\end{array}$ & 50,09 & 341,372 & ,667 & ,941 \\
\hline $\begin{array}{l}\text { Coping Strategy: Keeping control } \\
\text { over my emotions so that I am not }\end{array}$ & 50,18 & 342,204 & ,637 & ,941 \\
\hline
\end{tabular}


affected by what is stressing me

Coping strategy: Recall similar situations that have occurred in the past and think about how you will

$50,27 \quad 342,557 \quad, 619$

,942

deal with them

Coping strategy: Developing a plan to

deal with the stress and executing its

$50,60 \quad 345,792$

, 513

,943

tasks

Coping Strategy: Seek to get the

positive out of the situation you are

$50,21 \quad 345,036$

, 560

,943

concerned about

Source: CISCO Inventory Processing with SPSS.

\section{Presence of academic stress}

Using the results of the filter question of the SISCO Inventory instrument applied to the students under study, it was observed that, during the course of the semester under study, $93.3 \%$ of the students have experienced moments of worry or nervousness (stress), as shown in Table 2.

Table 2. Presence of academic stress

\begin{tabular}{ccc}
\hline $\begin{array}{c}\text { Presence } \\
\text { of stress }\end{array}$ & Frequency & Percentage \\
\hline Yes & 379 & $93.3 \%$ \\
Not & 27 & $6.7 \%$ \\
Total & $\mathbf{4 0 6}$ & $\mathbf{1 0 0 \%}$ \\
\hline
\end{tabular}

Source: CISCO Inventory Processing with SPSS.

\section{Intensity of academic stress}

The intensity of stress is measured by processing the second item of the instrument applied only to those respondents who expressed the presence of stress (at $93.3 \%$ of the selected sample). As it can be seen, $37.7 \%, 27.7 \%$ and $17.9 \%$ show levels of stress ranging from intensity 3,4 and 5 respectively, considering that 5 is the level of high stress. The results in figure 1 , indicate the need for further study of the various stressors, the reactions (symptoms) and the various forms of coping that the students have chosen.

While question 2 of the instrument allows for the analysis of the intensity of stress from the perspective of self-perception, it is an important indicator for addressing the analysis after processing the responses of the 21 items aimed at analyzing stressors and reactions to stress.

Figure 1. Intensity of academic stress for masters and doctoral students 


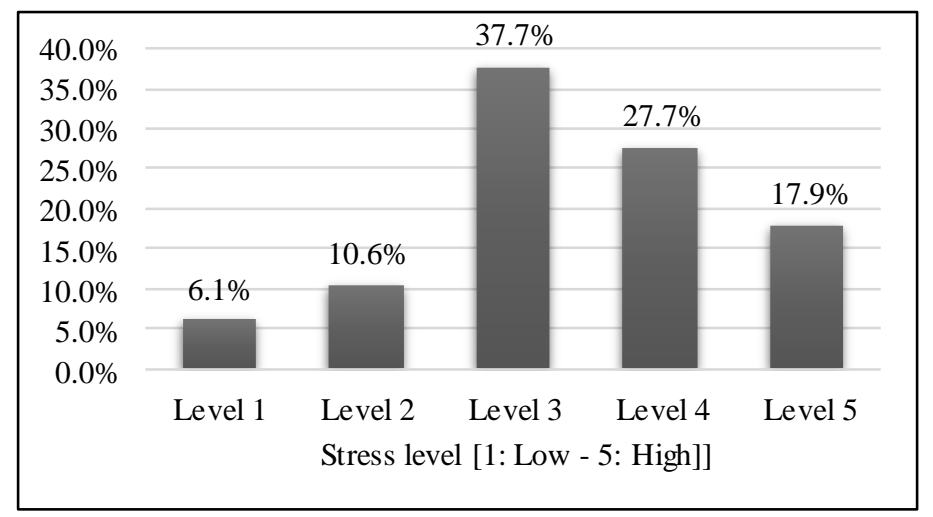

Source: CISCO Inventory Processing with SPSS.

Environmental demands as stressful stimuli

The most significant stressors or those with the greatest presence in the students who reported having experienced stress situations during the academic semester studied are the following: a) The overload of homework and daily school work, which sometimes, almost always and always generates stress for $69.4 \%$ of the students, b) The limited time to do the work, which sometimes, almost always and always generates stress for $59 \%$ of the students. $3 \%$ of the students, c) The type of work requested by teachers, such as essays, progress reports of thesis work, generates stress sometimes, almost always and always to

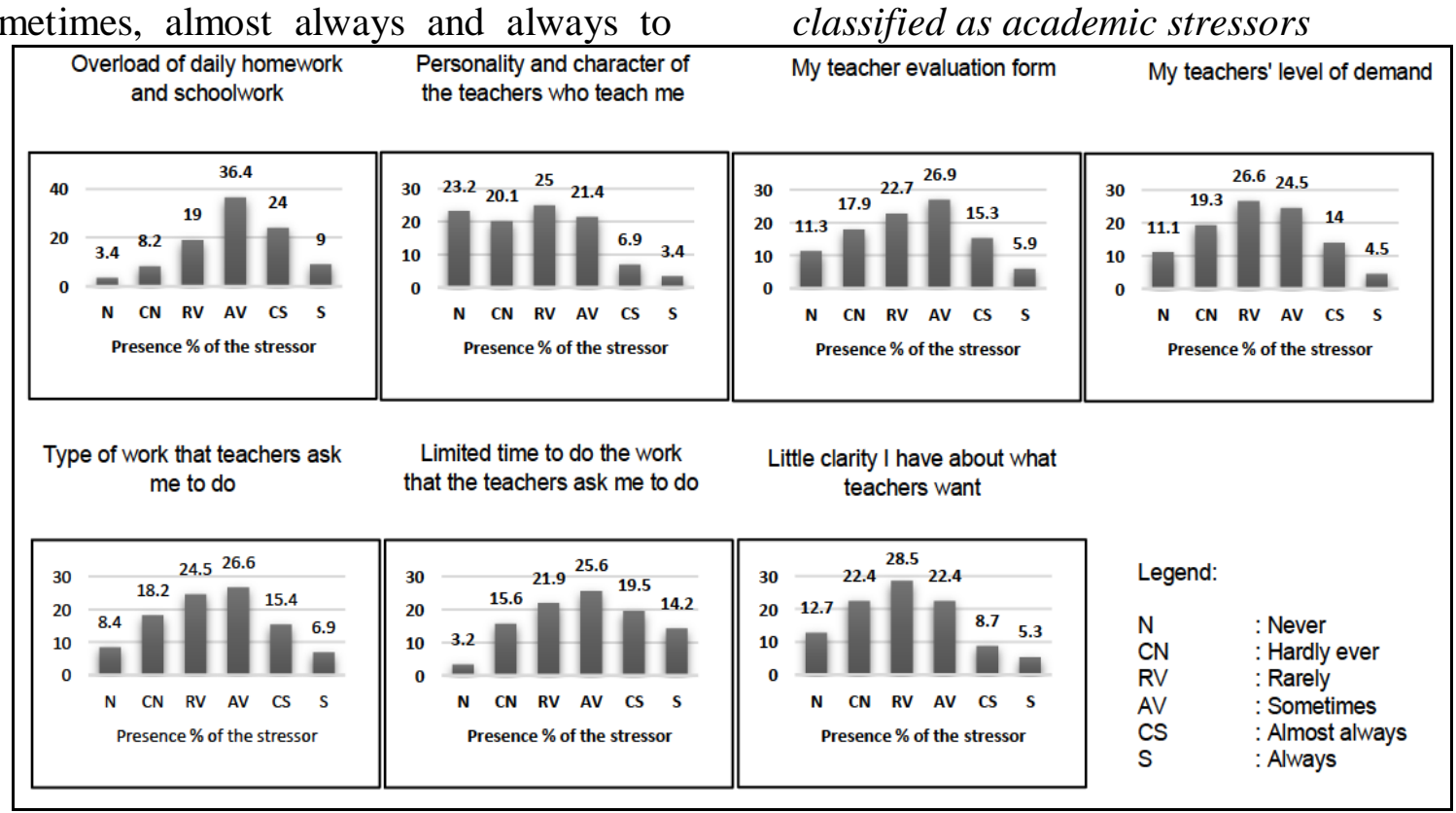

Source: CISCO Inventory Processing with SPSS.

Using the SISCO Inventory scale for measuring academic stress based on stress stimuli, the levels

Figure 3. Intensity of academic stress for masters and doctoral students
$48.9 \%$ of the students, d) The form of evaluation of the teachers generates stress sometimes, almost always and always to $48.1 \%$ of the students, e) The level of demand of the teachers generates stress to $43 \%$ of the students sometimes, almost always and always. Other stressors such as the character of the teachers and the fact that they do not clearly understand what the teachers are really demanding sometimes, almost always and always generate stress between $31.7 \%$ and $36.4 \%$. A comprehensive graphical view of the frequency with which the demands of the environment are valued as stressful stimuli can be seen in Figure 2. Figure 2. Elements of the academic environment classified as academic stressors
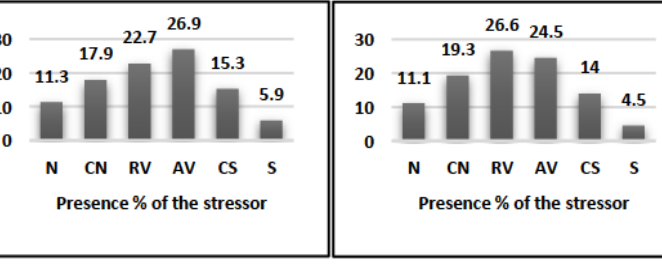

of academic stress are identified. Figure 3 shows that $48.2 \%$ present mild stress levels, $22.3 \%$ moderate stress and $29.5 \%$ severe stress. 


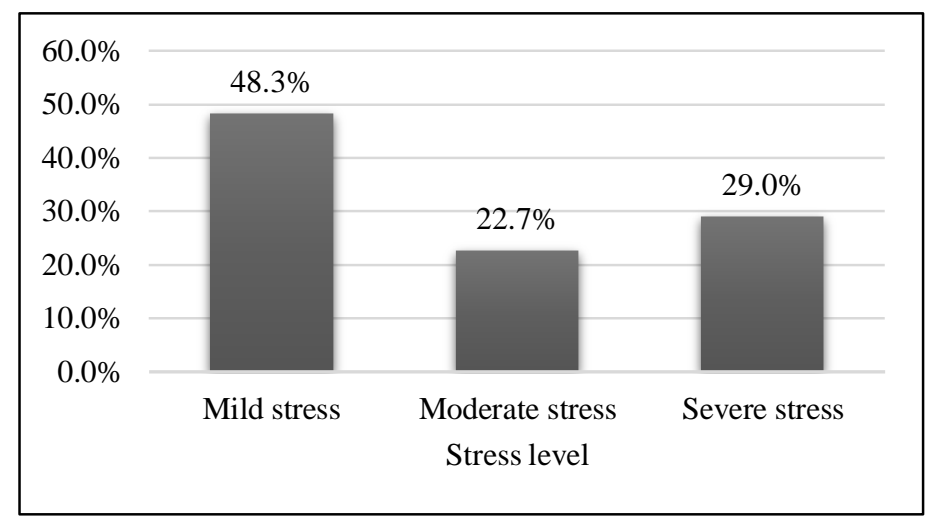

Source: CISCO Inventory Processing with SPSS.

Symptoms or reactions to a stress stimulus

The following information allows us to observe the reactions that occur in students when they are stressed: a) Anxiety, anguish or despair are reactions that occur sometimes, almost always and always in $50.7 \%$ of students, b) Chronic fatigue (permanent tiredness) is a reaction that occurs sometimes, almost always and always in $47.8 \%$ of students, c) Concentration problems are also a Figure 4. Symptoms or reactions to a stress stimulus reaction that occurs sometimes, almost always and always in $47.5 \%$ of students. Reactions such as conflict or tendency to argue or argue, feelings of aggression or increased irritability, unwillingness to do school work and feelings of depression and sadness are sometimes, almost always and always present in $28.3 \%$ to $37.5 \%$ of students. Figure 4 allows us to graphically observe students' reactions to the presence of academic stress.

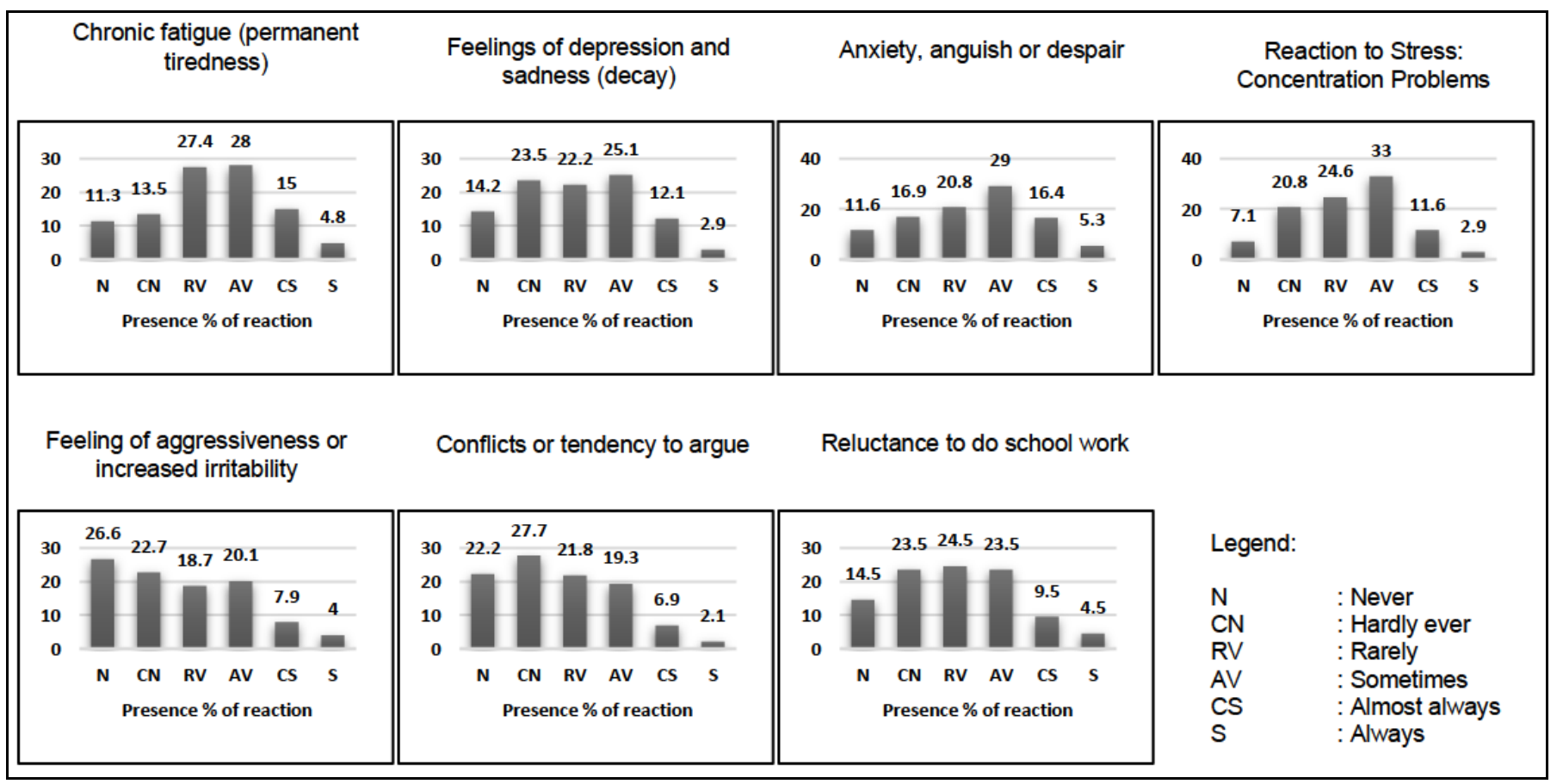

Source: CISCO Inventory Processing with SPSS.

\section{Coping strategies for academic stress}

Academic stress is considered a systemic process, of an adaptive nature and essentially psychological, which is presented in a descriptive manner in three moments, such as subjection to stressors (Barraza, 2007), which cause a systemic imbalance (stressful situation) and the coping 
actions to re-establish the balance. In this section the coping actions identified with the application of the SISCO Inventory are presented.

The most representative coping strategies are a) Analysis of the positive and negative aspects of the solutions designed to solve the situation that generates the stress. This strategy is sometimes, almost always and always present in $74.7 \%$ of the students, b) Establishing concrete solutions for solving situations that generate stress is sometimes, almost always and always present in $73.1 \%$, c) Keeping control over the emotions so that it does not affect the situation of stress is sometimes, almost always and always present in $726 \%$, d) Concentrating on resolving the situation that generates the concern is sometimes, almost always and always present in $71.7 \%$ of students and e) Looking at or trying to get the positive out of the situation that generates the concern is sometimes, almost always and always present in $69.2 \%$ of students. Other coping strategies such as remembering similar situations that have occurred previously and thinking about how to solve them and developing a plan to deal with the stress and execution of their tasks are sometimes, almost always and always present in $69.3 \%$ and $59.9 \%$ respectively.

Figure 5 gives a graphic image of the different strategies chosen by students who find themselves in situations of systemic imbalance (stressful situation) in order to restore the situation of equilibrium.

\section{Figure 5. Stress management strategies}

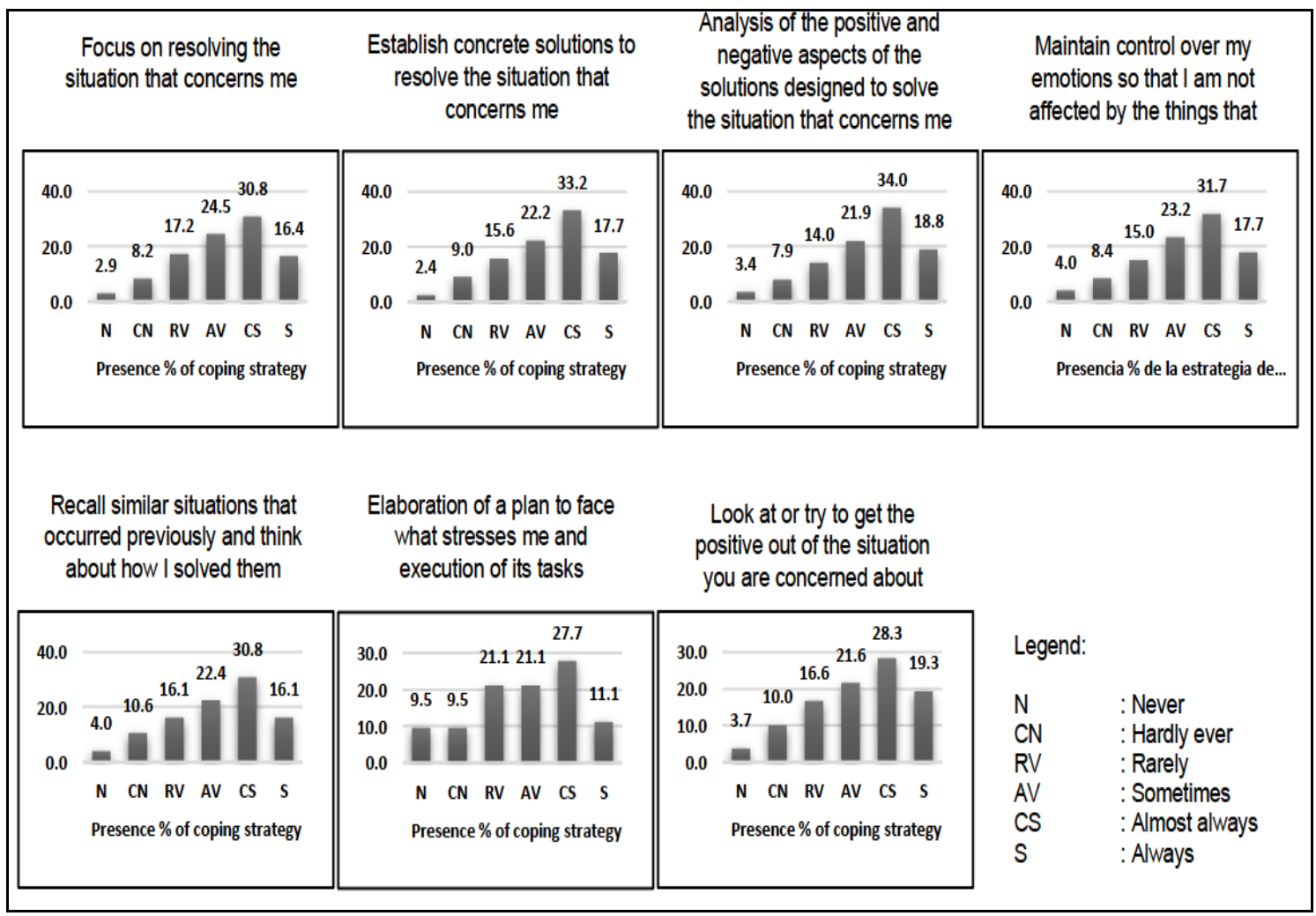

Source: CISCO Inventory Processing with SPSS.

\section{Discussion}

The results obtained on stress in masters and doctorate students at the Universidad César Vallejo, Peru, show that, during the course of the semester under study, $93.3 \%$ of students have experienced moments of concern or nervousness (stress), which are consistent with the studies of (Odriozola-González et al., 2020) and (Sahu, 2020) who consider that the general impact on 
education and mental health in the Spanish university environment caused by the COVID-19 infection is considerable, resulting in a notable increase in student stress.

The identification of the main stressors such as a) The overload of tasks and daily school work, which sometimes, almost always and always generate stress to $69.4 \%$ of students, b) The limited time to do the development of work, generate stress sometimes, almost always and always to $4895 \%$ of the students, among others, are aligned with the results found in previous studies indicating that psychological impacts affected at the level of health professionals, but also among medical students due to increased stress, anxiety and depression, even more so if they are in contact with infected people (Wu et al., 2020).

Furthermore, that academic stress can also be caused by academic stressors in the teaching and learning process or in matters related to learning activities (Sari et al., 2020). Other results present findings related to higher levels of stress and depression symptoms, which occurred after the order to stay home was issued (Ozamiz-Etxebarria et al. 2020). Finally, the main stressor that generates high levels of stress is academic overload, affecting university students so much that they had to resort to religion to cope with it (Pedroza et al., 2019).

\section{Conclusions}

During the COVID-19 pandemic, master's and doctoral students at the Universidad César Vallejo in Peru faced stress. $93.3 \%$ of the students have experienced moments of worry or nervousness (stress) when taking on their academic tasks.

With respect to the intensity of the stress it is observed that $37.7 \%, 27.7 \%$ and $17.9 \%$ show stress levels 3, 4 and 5 respectively, considering that 5 is the level of much stress. Then, there are
$83.3 \%$ of the students who reported the presence of stress that, in addition, are at intermediate to high stress levels.

The elements of the academic environment that are most present as stressors are: a) The overload of daily homework and school work, b) The limited time to do the development of work and c) The type of work requested by the teachers, such as essays, progress reports of thesis work.

The main reactions or symptoms to the presence of stressors in the academic environment were from the highest to the lowest level: a) Anxiety, anguish or despair are reactions that sometimes, almost always and always occur in $50.7 \%$ of students, b) Chronic fatigue (permanent tiredness) is a reaction that sometimes, almost always and always occurs in $47.8 \%$ of students and c) Concentration problems are also a reaction that sometimes, almost always and always occurs in $47.5 \%$ of students.

The most significant coping strategies used by the students to deal with stressful situations where: a) Analysis of the positive and negative aspects of the solutions designed to solve the situation that generates the stress. This strategy is present at times, almost always and always in $74.7 \%$ of the students, b) Establishing concrete solutions for solving situations that generate stress is present at times, almost always and always in $73.1 \%$, c) Keeping control over emotions so that it does not affect the situation of stress is present at times, almost always and always in 72 6\%, d) Concentrating on resolving the situation that generates the concern is sometimes, almost always and always present in $71.7 \%$ of students and e) Looking at or trying to get the positive out of the situation that generates the concern is sometimes, almost always and always present in $69.2 \%$ of students.

Limitations of this study: Regardless of the fact that the results indicate the presence of high levels 
of stress in the postgraduate students under study, it is noted that these data have been taken in the middle of COVID-19 in Peru and therefore could vary in other pandemic scenarios such as outbreaks, virus mutations or mass vaccination campaigns. Since this is not the main purpose of the study, the incidence of media information and the socio-cultural dynamics of Peru were disregarded as collateral factors prone to generate academic stress in postgraduate students, however, these are variables that, due to their relevance, should be addressed in future studies.

Conflicts of interest: authors do not declare conflicts of interest

\section{References}

1. Adom, D., Essel, H. B., \& Chukwuere, J. E. (2020). Academic Stress among Faculty and Students in Higher Institutions of Ghana: Sources, Causes and Coping Mechanisms. Pertanika Journal of Social Sciences and Humanities, 28(2), 10551064. https://events.aau.org/corevip/wpcontent/uploads/sites/3/2019/12/Academic -Stress-among-Faculty-and-Students-inHigher-Institutions-of-Ghana.pdf

2. Alania Contreras, R. D., Llancari Morales, R. A., De la Cruz, M. R., \& Ortega Révolo, D. I. D. (2020). Adaptation of the SISCO SV academic stress questionnaire to the context of the crisis by COVID- 19 . Socialium, 4(2), 111-130. https://doi.org/10.26490/uncp.sl.2020.4.2. 669

3. Barraza, A. (2007). El Inventario SISCO del Estrés Académico. Investigación Educativa Duranguense, 7, 90-93.

4. Fernández-Sánchez, H., Gómez-Calles, T. J., \& Pérez-Pérez, M. (2020). Intersección de pobreza y desigualdad frente al distanciamiento social durante la pandemia COVID-19. Revista Cubana de Enfermería, 36, 1-15. http://revenfermeria.sld.cu/index.php/enf/a rticle/view/3795/618

5. Hernandez, R., Fernandez, C., \& Baptista, P. (2014). Metodología de la investigación (Vol. http://observatorio.epacartagena.gov.co/wp -content/uploads/2017/08/metodologia-dela-investigacion-sextaedicion.compressed.pdf

6. Lozano Díaz, A., Canosa, V. F., Fernández Prados, J. S., \& Martínez, A. M. M. (2020). Impacts of COVID-19 Confinement among College Students: Life Satisfaction, Resilience and Social Capital Online. International Journal of Sociology of Education, 9(1), 1-27. https://doi.org/10.17583/rise.2020.5925

7. Mahapatra, A., \& Sharma, P. (2020). Education in times of COVID-19 pandemic: Academic stress and its psychosocial impact on children and adolescents in India. International Journal of Social Psychiatry, 10-12. https://doi.org/10.1177/002076402096180 1

8. Odriozola-González, P., PlanchueloGómez, Á., Irurtia, M. J., \& de LuisGarcía, R. (2020). Psychological effects of the COVID-19 outbreak and lockdown among students and workers of a Spanish university. Psychiatry Research, 290. https://doi.org/10.1016/j.psychres.2020.11 3108

9. OPS. (2019). Protección de la salud mental en situaciones de epidemias. In Organización Panamericana de la Salud. https://www.paho.org/hq/dmdocuments/20 09/Pandemia de influenza y Salud mental Esp.pdf

10. Ozamiz-Etxebarria, N., Dosil-Santamaria, M., Picaza-Gorrochategui, M., \& IdoiagaMondragon, N. (2020). Stress, anxiety, and depression levels in the initial stage of the COVID-19 outbreak in a population sample in the northern Spain. Cadernos de Saude Publica, 36(4), e00054020. https://doi.org/10.1590/0102311X00054020

11. Pedroza, J., Cabrera, L., \& Gutiérrez, M. (2019). Factores que influyen en el estrés académico. Revista Navarra Médica, 5(2), 14-23.

https://journals.uninavarra.edu.co/index.ph p/navarramedica/article/download/198/96

12. Procentese, F., Capone, V., Caso, D., Donizzetti, A. R., \& Gatti, F. (2020). 
Academic community in the face of emergency situations: Sense of responsible togetherness and sense of belonging as protective factors against academic stress during covid-19 outbreak. Sustainability (Switzerland), 12(22), 1-12. https://doi.org/10.3390/su12229718

13. Ribot Reyes, Victoria de la Caridad, Chang Paredes, Niurka, González Castillo, A. L. G. (2020). Efectos de la COVID-19 en la salud mental de la población. Efectos de La COVID-19 En La Salud Mental de La Población, 6(5), 1-15. http://scielo.sld.cu/scielo.php?pid=S1729519X2008000300003\&script=sci_arttext

14. Rodríguez De Los Ríos, L., Nacional De Educación, U., Guzmán, E., Lima-Perú, V., Peña, A. Q., Nacional, U., De San, M., Lima, M., Jaime, P., Tovar, A., Brian, P., Peña-Calero, N., \& San, D. (2020). Análisis Psicométrico Preliminar de la escala Perfil de Impacto Emocional. Revista Sobre Educación y Sociedad, 2020(15), 5-22. https://doi.org/10.35756/educaumch.v1i15. 135

15. Sahu, P. (2020). Closure of Universities Due to Coronavirus Disease 2019 (COVID-19): Impact on Education and Mental Health of Students and Academic Staff. Cureus, 12(14), e7541-undefined. https://doi.org/10.7759/cureus.7541

16. Sari, P., Pajarianto, H., Kadir, A., Galugu, N., \& Februanti, S. (2020). Study from Home in the Middle of the COVID-19 Pandemic: Analysis of Religiosity, Teacher, and Parents Support Against Academic Stress. 12(2s), 1791-1807. https://iratde.com/index.php/jtde/article/vi ew/830

17. Segura, M. S. (2020). Con alerta pero sin pánico. El rol de los medios durante la pandemia. Revista de La Facultad de Ciencias Médicas de Córdoba, 77(1), 5558.

https://doi.org/10.31053/1853.0605.v77.n1 .28066

18. Trigueros, R., Padilla, A., Aguilar-Parra, J. M., Lirola, M. J., García-Luengo, A. V., Rocamora-Pérez, P., \& López-Liria, R. (2020). The Influence of Teachers on
Motivation and Academic Stress and Their Effect on the Learning Strategies of University Students. International Journal of Environmental Research and Public Health, 17(23), 9089. https://doi.org/10.3390/ijerph17239089

19. Wu, S., Li, Z., Li, Z., Xiang, W., Yuan, Y., Liu, Y., \& Xiong, Z. (2020). The mental state and risk factors of Chinese medical staff and medical students in early stages of the COVID-19 epidemic. Comprehensive Psychiatry, 102, 152202. https://doi.org/10.1016/j.comppsych.2020. 152202

20. Zhang, X., Li, X., Liao, Z., Zhao, M., \& Zhuang, Q. (2020). Evaluation of psychological stress in scientific researchers during the 2019-2020 COVID-19 outbreak in China. PeerJ, 8, e9497-undefined.

https://doi.org/10.7717/peerj.9497 